\title{
THE LUBRICITY AND RHEOLOGICAL PROPERTIES OF MAGNETORHEOLOGICAL FLUIDS
}

\section{WŁAŚCIWOŚCI SMARNE I REOLOGICZNE CIECZY MAGNETOREOLOGICZNYCH}

\author{
Emil Nowiński \\ e-mail:emil.nowinski@itwl.pl
}

\begin{abstract}
The article presents results of tribological research carried on four ball tester and dynamic rheometer for different magnetorheological fluids. The wear test was conducted with and without magnetic field. The dynamic rheology measurement was done at wide range of velocity. The inteligent fluids differed from each other by an amount of solid phase and kind of base liquid.
\end{abstract}

Keywords: lubricity, wear, magnetorheological fluids, inteligent fluids

Streszczenie: $W$ publikacji przedstawiono wyniki badań tribologicznych przeprowadzonych na aparacie czterokulowym i reometrze dynamicznym z użyciem różnych cieczy magnetoreologicznych. Testy przeprowadzone byly z użyciem $i$ bez użycia pola magnetycznego. Pomiar właściwości reologicznych prowadzony byt w szerokim zakresie prędkości ścinania. Badane ciecze różnity się od siebie ilościa fazy statej oraz rodzajem cieczy bazowej.

Stowa kluczowe: smarność, zużycie, ciecze magnetoreologiczne, ciecze inteligentne 


\section{THE LUBRICITY AND RHEOLOGICAL PROPERTIES OF MAGNETORHEOLOGICAL FLUIDS}

\section{Introduction}

The applications of magnetorheological fluids are commonly known today. They are primarily used as working fluids in devices, such as shock absorbers and clutches [2,3]. The changes of rheology of these fluids, obtained as a result of the magnetic field impact, allow to control the properties of these fluids, and thus to control the resistance of movement of the devices, in which these fluids are located. Magnetorheological fluids are also used for polishing elements that are subject to such treatment [1]. Such a use of these substances is possible thanks to very fine metal particles contained in magnetorheological fluids. Depending on the size of magnetically active particles, it is possible to obtain a better or worse polishing effect. A similar effect will occur in case of devices, where the working substance constitutes a magnetorheological fluid.

Despite the fact that literature does not present the effects of an adverse impact of the magnetorheological fluid on the moving machines' elements in the environment of these fluids, the cases of very short durability of devices powered by such fluids as, e.g. shock absorbers in sports cars, are known.

In many publications, there is information about attempting to lubricate friction pairs (bearings, gears) with magnetorheological fluids and ferrofluids. In this case, it is appropriate to carry out the tests of lubricity properties of such substances. This publication presents the results of evaluation of lubricity properties of three magnetorheological fluids, which differ in terms of the chemical composition. One of the tested substances is a fluid available commercially, however, the other two are composed according to own recipes.

The research purpose was to determine the impact of the content of carbonyl iron particles and the base liquid type on the wear intensity of the friction pair operating in extreme conditions. This research was also expected to provide an answer of what impact on the wear intensity has the introduction to the magnetic field friction pair.

\section{Methodology and research subject}

The research subject included three magnetorheological fluids marked as MRF 1, MRF 2 and MRF 3. The obtained results of wear for friction pairs lubricated with magnetorheological fluids were compared with the results for base liquids, which were the solid phase carrier fluids in the composed magnetorheological fluids.

The first fluid, which is subject to the assessment, constitutes a commercial product marked as MRF 3. It is a magnetorheological fluid containing approx. $80 \%$ of the solid phase dispersed in the hydrocarbon base. 
It is used in the applications such as shock absorbers, clutches and magnetic brakes. The next two were designed in the Air Force Institute of Technology, and the fluid marked as MRF 1 was prepared on the basis of PAO synthetic oil with viscosity of $40 \mathrm{~mm}^{2} / \mathrm{s}$ at $100^{\circ} \mathrm{C}$, and the one marked as MRF 2 - on the basis of 1, 2 - propylene glycol. In case of both prepared magnetorheological fluids, the solid phase content, which included BASF company carbonyl iron with a grain size of $4 \mu \mathrm{m}$ was $4: 10$ in relation to the weight of the fluid, in which these particles were suspended. As an additive dispersing metallic particles, colloidal silica in the medium-sized particle of $50 \mathrm{~nm}$ was used.

A list of some parameters of three magnetorheological fluids and two base liquids was presented in Table 1 .

Table 1 Some physico-chemical properties of tested magnetorheological fluids and base liquids.

\begin{tabular}{|l|c|c|c|c|c|}
\hline & MRF 1 & MRF2 & MRF 3 & PAO 40 & $\begin{array}{c}\text { Polypropylene } \\
\text { glycol }\end{array}$ \\
\hline Flash point & 256 & 143 & 150 & 281 & 130 \\
\hline $\begin{array}{l}\text { Density } \\
{\left[\mathrm{g} / \mathrm{cm}^{3}\right]}\end{array}$ & 1.47 & 1.61 & 3.10 & 0.79 & 1.03 \\
\hline $\begin{array}{l}\text { Solid phase } \\
\text { content [\%] }\end{array}$ & 40 & 40 & 80.98 & - & - \\
\hline $\begin{array}{l}\text { Base liquid } \\
\text { type }\end{array}$ & PAO 40 & $\begin{array}{c}\text { Polypropylene } \\
\text { glycol }\end{array}$ & $\begin{array}{c}\text { Synthetic } \\
\text { oil }\end{array}$ & - & - \\
\hline
\end{tabular}

The research of tribological properties of the friction pair lubricated with magnetorheological fluids was carried out on Stanhope Seta four-ball tester. This is a device that is used to evaluate the lubricity properties of lubrication substances according to ASTM D 2783-03 Standard Test Method for Measurement of Extreme-Pressure Properties of Lubricating Fluids and ASTM 2266 -01 Standard Test Method for Wear Preventive Characteristics of Lubricating Grease.

In the assumed methodology, 1 minute gears at the speed of $1450 \mathrm{rpm}$ under the load of $785 \mathrm{~N}$ ( $80 \mathrm{~kg}$ ) were implemented. The load was experimentally chosen taking into account extreme operating conditions of sliding bearings, and also minimum loads which are imposed on lubricants in tests on the four ball tester. The friction pair included bearing balls with a diameter of $12.7 \mathrm{~mm}$ made of $Ł H 15$ steel (Fe iron alloy containing the average of $1 \% \mathrm{C}, 0.02 \% \mathrm{~S}, 0.3 \% \mathrm{Ni}, 0.3 \% \mathrm{Cu}$ ) in the accuracy class of 16 according to PN-83/M-86452 standard, immersed in the tested magnetorheological fluid. 
The lubricity and rheological properties of magnetorheological fluids Wtaściwości smarne i reologiczne cieczy magnetoreologicznych

In Figure 1, a view of the four ball tester and the friction pair of this device were presented.

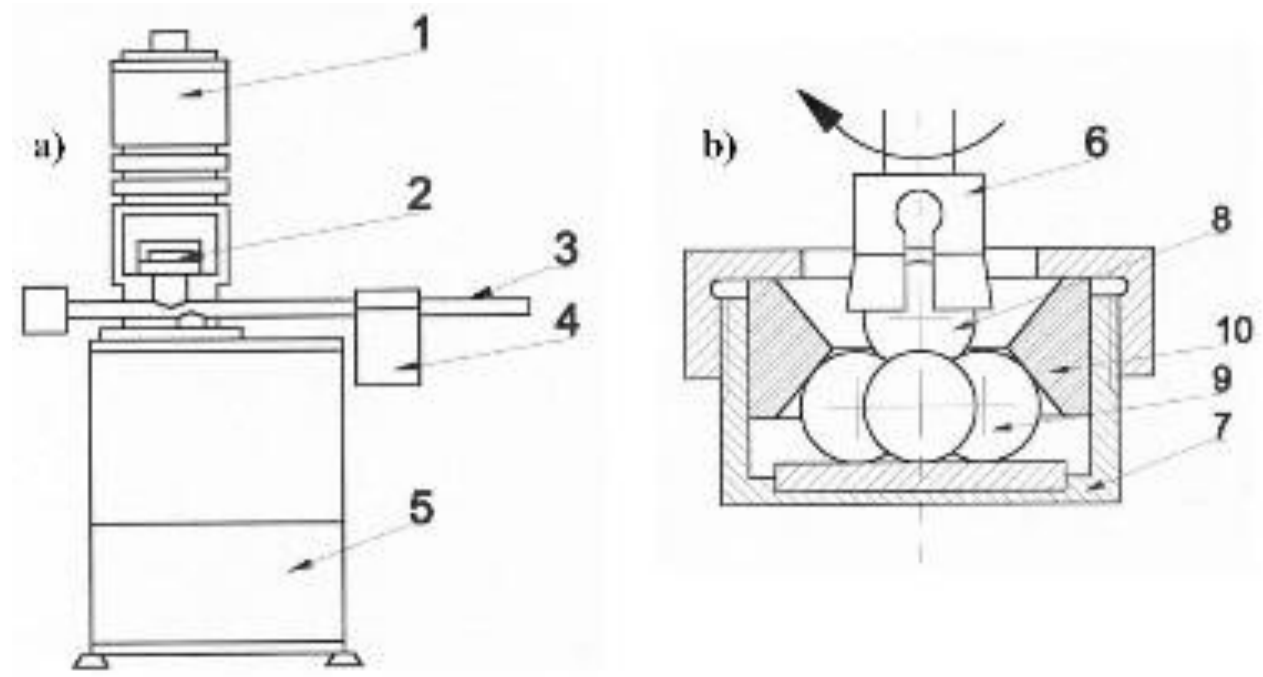

Fig. 1. View of the four ball tester ( $a$ ) and the friction pair (b);

1 - engine, 2 -friction pair, 3 -loading arm, 4-load, 5-base,

6 - handle of the ball implementing the rotary motion, 7 - handle for three balls,

8 - nut stabilising the pair, 9 - balls, 10 -locator ring

The research of lubricity properties was carried out in the conditions of the magnetic field influence on the friction pair, as well as without the impact of this field. The magnetic field was generated by neodymium magnets placed on the handle of balls, as in Figure 2.

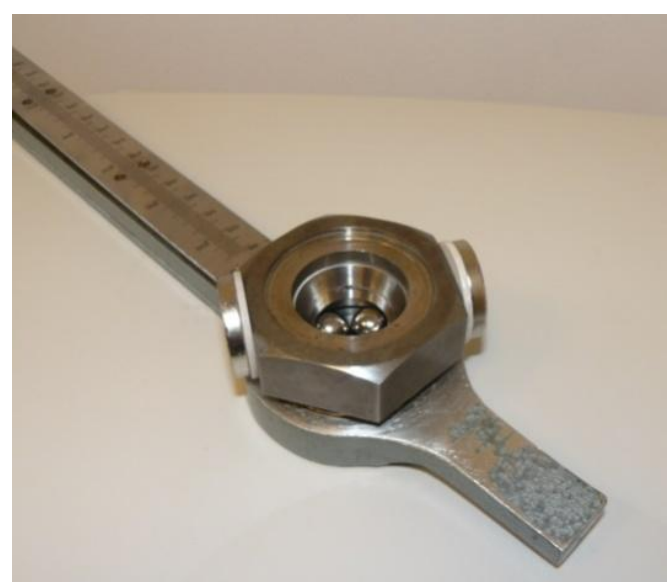

Fig. 2. View of the handle of friction elements with neodymium magnets that are a source of the magnetic field 
In addition to the lubricity properties of the tested fluids, the assessment of changes in their viscosity under the influence of the applied magnetic field and changes in the sliding speed were carried out. These marks were made on ARES TA Instruments rotational rheometer.

The measurements were carried out in the plate - plate relation (plate diameter $\varphi=20 \mathrm{~mm}$ ) at a constant distance between the plates $1 \mathrm{~mm}$. The system of these plates was presented in Figure 3.

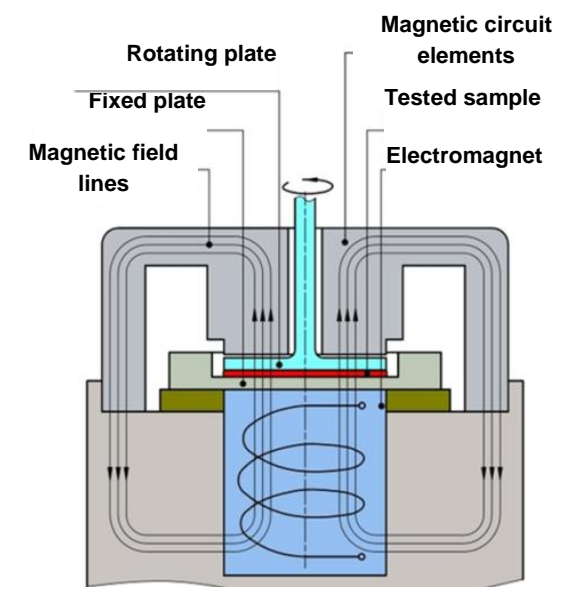

Fig. 3. Diagram of the electromagnetic field impact on the magnetorheological fluid between working plates.

The research of rheological properties was conducted in the variable shear rate function in the range of $0.1-630 \mathrm{~s}^{-1}$. A sample of the fluid was placed at the bottom plate while the other plate immersed in this fluid carries out the rotation motion. For each of the tested materials, the rheological characteristics at specific parameters for three repetitions was determined. The changes of viscosity, shear stress and rotational torque in the shear rate function were recorded. On the basis of the conducted measurements, changes in viscosity in the shear rate function without the field and in the magnetic field with a strength of $159 \mathrm{kAm}^{-1}$ were showed.

\section{Research results}

The results of lubricity tests carried out on the four ball tester for three magnetorheological fluids and two base liquids were provided in the form of a graph in Figure 4.

As it results from the obtained research results, the greatest wear, and thus, the worst lubricity in the specified operation conditions was characteristic of the magnetorheological commercial fluid, marked as MRF 3. Despite a scheduled test lasting 60 seconds, after several seconds of the test duration, the seizing of balls operating in the fluid environment took place, and in the 25th second of the test, the research was interrupted due to the welding of balls. 


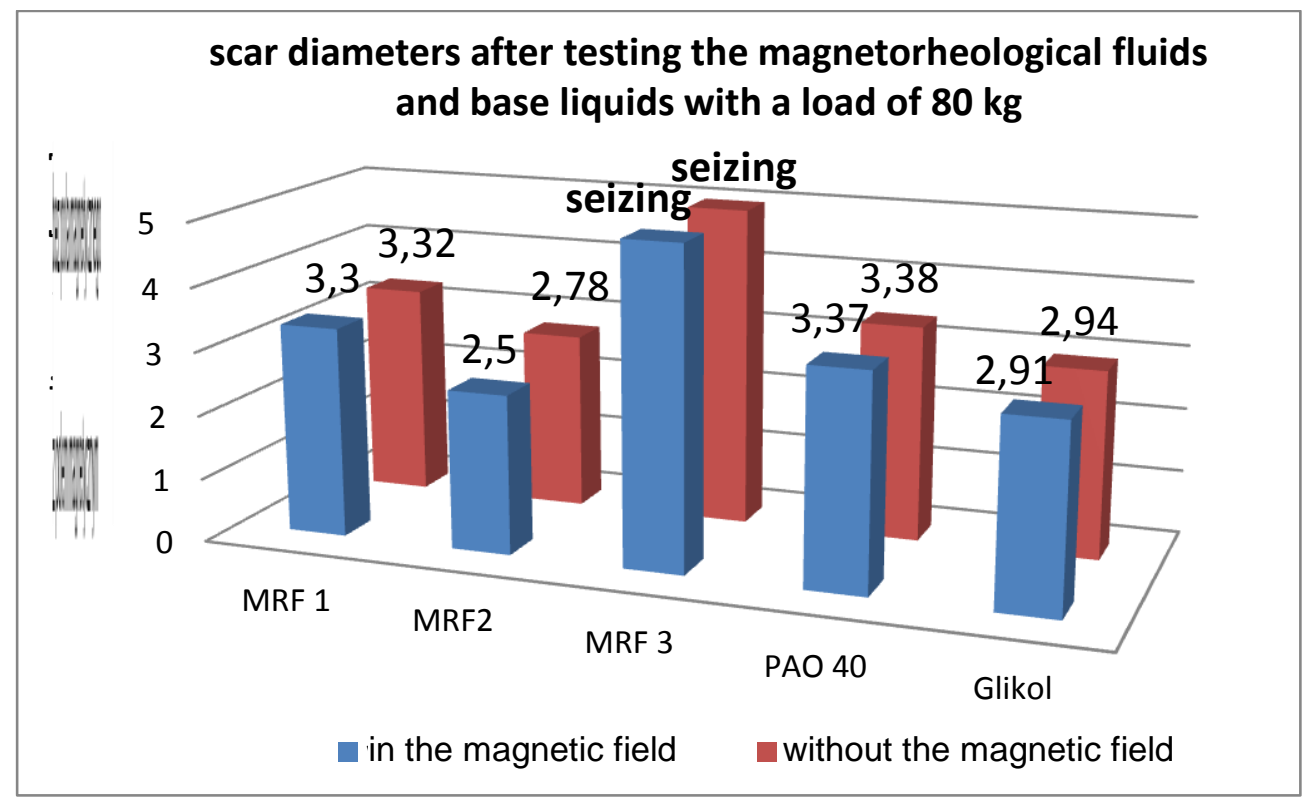

Fig. 4. The wear values of the friction pair lubricated with magnetorheological fluids with the impact and without the impact of the magnetic field.

MRF 1 and MRF 2 fluids were characterised by much better results during the lubricity test. During the trials with these fluids, the seizing did not occur, and the friction pair withstood a given load of $80 \mathrm{~kg}$. The friction result in the magnetorheological fluid environment included the wear of cooperating balls. The lowest wear was characteristic of the friction pair lubricated with MRF 2 composed on the basis of polypropylene glycol. The average wear scar diameter for the test with the fluid on the basis of polypropylene glycol was $2.78 \mathrm{~mm}$ in the conditions without the magnetic field impact. After placing near the friction pair of neodymium magnets, the wear scar was lower and amounted to $2.50 \mathrm{~mm}$.

In case of the tribological test with the use of MRF 1 fluid prepared on the basis of PAO 40 oil, the wear scar diameters were higher than during testing with MRF 2 fluid. The experiment results in the magnetic field and without the magnetic field did not differ significantly from each other and were respectively $3.30 \mathrm{~mm}$ and $3.32 \mathrm{~mm}$.

By referring the obtained results to the lubricity results, which were obtained for pure bases of carrier substances of magnetorheological fluids, there is a certain analogy involving better antiwear properties both of glycol and the magnetorheological fluid prepared on its basis, in relation to PAO 40 oil and its derivative.

Taking into account the magnetic field impact on lubricity properties of the tested fluids, it should be found that it is positive in case of MRF 1 and MRF 2 magnetorheological fluids, as shown by smaller wear diameters. 
In case of the commercial fluid, the magnetic field impact cannot be assessed due to the trials, which ended with the friction pair seizing in both cases. However, as expected, the magnetic field did not influence the lubricity test results for pure base liquids (PAO 40 oil and polypropylene glycol).

In order to correctly interpret the obtained results, the density measurement of tested magnetorheological fluids can be also helpful. Having the knowledge of base liquids, and also of the content of carbonyl iron powder or density of magnetorheological fluids, it is possible to assess the impact of the metallic solution solid phase content on lubricity properties of magnetorheological fluids. Taking into account the data in Table 1, MRF 1 fluid had the lowest density of magnetorheological fluids, and that was $1.47 \mathrm{~g} / \mathrm{cm}^{3}$. A slightly higher density was characteristic of MRF 2 fluid $-1.61 \mathrm{~g} / \mathrm{cm}^{3}$, and the commercial fluid had the highest density of $3.10 \mathrm{~g} / \mathrm{cm}^{3}$. On this basis, it can be concluded that the magnetorheological commercial fluid contained nearly twice as much carbonyl iron as MRF 1 and MRF 2 fluids. Therefore, a possible cause of poorer lubricity of MRF 3 fluids in the friction pair included the increased concentration of hard metallic particles, which led to the rapid seizing. Nevertheless, an additive of metallic particles to PAO 0 base liquids and polypropylene glycol (MRF 1 and MRF 2 fluids) not only results in increasing the friction pair wear scar, but it decreased the scar in case of the fluid based on glycol. The mechanism of such behaviour is unknown, but it should be assumed that a nano-sized dispersant, such as colloidal silica, as well as greater thermal conductivity compared to synthetic oil, contributed to it.

Bearing in mind not only lubricity properties, but also a key feature of magnetorheological fluids, which constitutes a change in rheology due to the magnetic field application, the comparison of the properties of magnetorheological fluids on ARES intended apparatus was performed.

Below, in figure 5, the results of the viscosity changes of 3 magnetorheological fluids in the shear rate function at the constant temperature of $20^{\circ} \mathrm{C}$, in which the assessment was made, were presented. In the graph, there are curves, among which the ones plotted with red are characteristic of viscosity changes in the tested fluid under the applied magnetic field with a strength of $200 \mathrm{mT}$, and those plotted with blue - viscosity changes at the magnetic field zero strength.

On the basis of the obtained results of rheology changes of three magnetorheological fluids: MRF 1, MRF 2 and MRF 3, it should be concluded that all the tested fluids showed the dispersion effect due to shearing. In the entire range of shear rate changes, significant differences in rheology of tested fluids that result from the differences in strength of the magnetic field, in which this fluid was maintained, were noticeable In relation to the fluids marked as MRF 1 and MRF 2, MRF 3 commercial fluid was characterised by higher viscosities in the entire range of shear rate changes. At the same time, the fluid showed the greatest viscosity change in the external magnetic field of $160 \mathrm{kAm}^{-1}(200 \mathrm{mT})$. 
The lubricity and rheological properties of magnetorheological fluids Wtaściwości smarne i reologiczne cieczy magnetoreologicznych

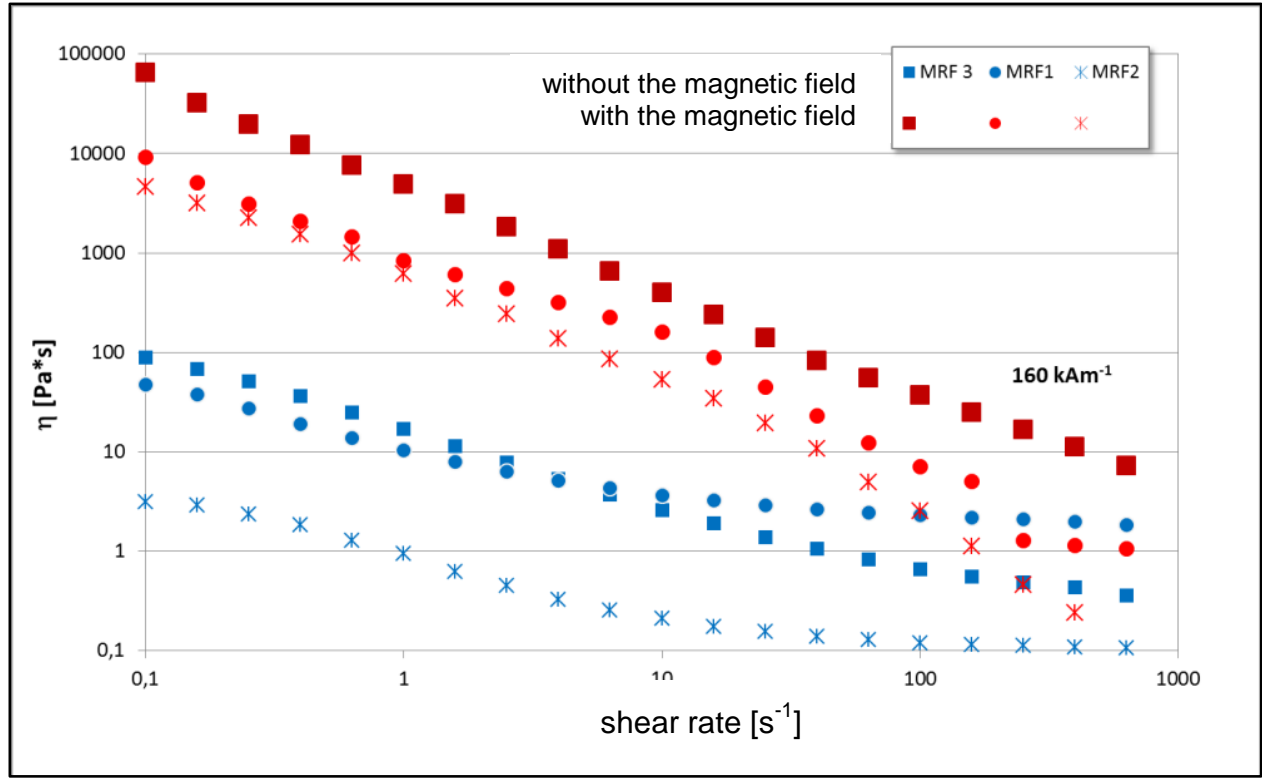

Fig. 5 Rheology changes in magnetorheological fluids at various shear rates and the different magnetic field strength.

The lowest viscosity changes and shear rate under the influence of the magnetic field among the tested materials are attributed to MRF 1 fluid prepared on the basis of PAO 40 oil. At low shear rates, the viscosity changes occurring under the influence of the applied field are similar both for MRF 1 and MRF 2 fluids. However, together with an increase of this rate, the viscosity changes for MRF 2 fluid, the basis of which is polypropylene glycol, are visible. In case of MRF 1 fluid, at the shear rate of approx. $100 \mathrm{rps}$ and higher, the applied magnetic field strength has no great influence on the fluid rheology. In this respect, MRF 2 fluid ranks much better.

\section{Conclusions}

On the basis of the obtained results of lubricity properties of the tested fluids and changes in rheology under the influence of the magnetic field, the following results can be presented:

- The tested magnetorheological commercial fluid is characterised by very poor lubricity and anti-seizing properties.

- An increase in the content of metallic particles in magnetorheological fluids deteriorates lubricity properties, but it improves magnetic properties.

- The type of the substance, in which metallic particles are suspended, influences lubricity properties and behaviour of magnetorheological fluids in the magnetic field. 
- The application of the magnetic field in friction pairs lubricated with magnetorheological fluids may influence the improvement of lubricity properties of these fluids.

- There is a need to optimize the lubricity and magnetic properties of magnetorheological fluids.

\section{References}

[1] Kyung-In Jang, JongwonSeok, Byung-KwonMin, SangJoLee: An electrochemomechanical polishing process using magnetorheological fluid. International Journal of Machine Tools \& Manufacture 50 (2010) 869-881;

[2] Muc A., Barski M.: Magnetorheological fluids and their practical application. Wydawnictwo Politechniki Krakowskiej [Publishing House of Cracow University of Technology], Kraków 2007;

[3] Bik T.: Ferrofluid technical application. Mechanik [Mechanic] 12/2015;

[4] ASTM D 2783 - 03. Standard Test Method for Measurement of ExtremePressure Properties of Lubricating Fluids (Four-Ball Method);

[5] J. Kozłowska, K. Kulikowski, M. Leonowicz: The tribological performance of magnetorheological fluids. International Conference BALTTRIB' 2013;

[6] W. H. Li and X. Z. Zhang, The effect of friction on magnetorheological fluids., Korea Aust. Rheol. J. 20, 4550, March 24, 2008;

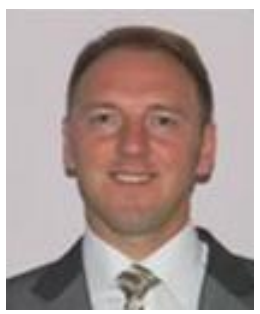

Emil Nowiński, Ph.D. Eng. - a senior research and technical specialist in the Air Force Institute of Technology. 


\section{WŁAŚCIWOŚCI SMARNE I REOLOGICZNE CIECZY MAGNETOREOLOGICZNYCH}

\section{Wstęp}

Zastosowania cieczy magnetoreologicznych są dziś powszechnie znane. Wykorzystuje się je głównie jako ciecze robocze w urządzeniach takich jak amortyzatory oraz sprzęgła [2,3]. Zmiany reologii tych cieczy uzyskane na skutek oddziaływania polem magnetycznym pozwalają na sterowanie właściwościami tych cieczy, a tym samym na sterowanie oporami ruchu urządzeń, w których ciecze te się znajdują. Ciecze magnetoreologiczne wykorzystywane są także do polerowania elementów poddanych takiej obróbce [1]. Na takie wykorzystanie tych substancji pozwalają bardzo drobne cząsteczki metali zawarte $\mathrm{w}$ cieczach magnetoreologicznych. W zależności od wielkości cząstek aktywnych magnetycznie, możemy uzyskać lepszy bądź gorszy efekt polerowania. Podobny efekt będzie miał miejsce w urządzeniach, gdzie substancją roboczą jest ciecz magnetoreologiczna.

Pomimo faktu, że literatura nie przedstawia efektów niekorzystnego wpływu cieczy magnetoreologicznych na elementy maszyn przemieszczające się w środowisku tych cieczy, znane są przypadki bardzo krótkiej trwałości urządzeń zasilanych takimi cieczami jak np. amortyzatory w samochodach sportowych.

W wielu publikacjach pojawiają się informacje o podejmowaniu prób smarowania węzłów tarcia (łożyska, koła zębate) cieczami magnetoreologicznymi czy ferrocieczami. W takim przypadku celowym jest przeprowadzanie badań właściwości smarnych takich substancji. W niniejszej publikacji przedstawiono wyniki oceny właściwości smarnych trzech cieczy magnetoreologicznych, różniących się od siebie składem chemicznym. Jedna z badanych substancji jest cieczą handlową, natomiast dwie pozostałe zostały skomponowane według własnych receptur.

Celem badań było określenie wpływu zawartości cząsteczek żelaza karbonylkowego oraz rodzaju cieczy bazowej na intensywność zużycia węzła tarcia, pracującego w ekstremalnych warunkach. Badania te miały również dać odpowiedź jaki wpływ na intensywność zużycia ma wprowadzanie do węzła tarcia pola magnetycznego.

\section{Metodyka i obiekt badań}

Obiektem badań były trzy ciecze magnetoreologiczne oznaczone jako MRF 1, MRF 2 i MRF 3. Uzyskane wyniki zużycia dla węzłów tarcia smarowanych cieczami magnetoreologicznymi porównano z wynikami dla cieczy bazowych, które były cieczami nośnymi fazy stałej w komponowanych cieczach magnetoreologicznych. 
Pierwszą z cieczy poddanych ocenie jest produkt handlowy oznaczony jako MRF 3. Jest to ciecz magnetoreologiczna zawierająca ok. $80 \%$ fazy stałej rozproszonej $\mathrm{w}$ bazie węglowodorowej. Jest ona stosowana $\mathrm{w}$ takich aplikacjach jak amortyzatory, sprzęgła i hamulce magnetyczne. Kolejne dwie zostały skomponowane w Instytucie Technicznym Wojsk Lotniczych, z czego ciecz oznaczona jako MRF 1 została sporządzona na bazie oleju syntetycznego PAO o lepkości $40 \mathrm{~mm}^{2} / \mathrm{s} \mathrm{w}$ temp. $100^{\circ} \mathrm{C}$, a oznaczona jako MRF 2 - na bazie glikolu 1,2 - propylenowego. W przypadku obu sporządzonych cieczy magnetoreologicznych zawartość fazy stałej, którą było żelazo karbonylkowe firmy BASF o wielkości ziarna $4 \mu \mathrm{m}$ wynosiła $4: 10 \mathrm{w}$ stosunku do masy cieczy, w której cząstki te zostały zawieszone. jako dodatek dyspergujący cząstki metaliczne zastosowana została krzemionka koloidalna w średniej wielkości cząsteczki wynoszącej $50 \mathrm{~nm}$.

Zestawienie niektórych parametrów trzech cieczy magnetoreologicznych i dwóch cieczy bazowych przedstawiono w tabeli 1 .

Tabela 1. Niektóre właściwości fizyczno - chemiczne badanych cieczy magnetoreologicznych i cieczy bazowych.

\begin{tabular}{|l|c|c|c|c|c|}
\hline & MRF 1 & MRF2 & MRF 3 & $\begin{array}{c}\text { PAO } \\
40\end{array}$ & $\begin{array}{c}\text { Glikol } \\
\text { polipro- } \\
\text { pylnowy }\end{array}$ \\
\hline $\begin{array}{l}\text { Temperatura } \\
\text { zapłonu }\end{array}$ & 256 & 143 & 150 & 281 & 130 \\
\hline $\begin{array}{l}\text { Gęstośc } \\
\left.\text { [g/cm }{ }^{3}\right]\end{array}$ & 1,47 & 1,61 & 3,10 & 0,79 & 1,03 \\
\hline $\begin{array}{l}\text { Zawartość } \\
\text { fazy stałej [\%] }\end{array}$ & 40 & 40 & 80.98 & - & - \\
\hline $\begin{array}{l}\text { Rodzaj cieczy } \\
\text { bazowej }\end{array}$ & PAO 40 & $\begin{array}{c}\text { Glikol } \\
\text { polipro- } \\
\text { pylenowy }\end{array}$ & $\begin{array}{c}\text { Olej } \\
\text { syntetyczny }\end{array}$ & - & - \\
\hline
\end{tabular}

Badania właściwości tribologicznych węzła tarcia smarowanego cieczami magnetoreologicznymi wykonano na aparacie czterokulowym firmy Stanhope Seta. Jest to urządzenie, które służy do oceny właściwości smarnych substancji smarowych według norm ASTM D 2783-03 Standard Test Method for Measurement of Extreme-Pressure Properties of Lubricating Fluids oraz ASTM 2266 -01 Standard Test Method for Wear Preventive Characteristics of Lubricating Grease.

W założonej metodyce realizowano biegi 1 minutowe z prędkością $1450 \mathrm{obr} / \mathrm{min}$. pod obciążeniem $785 \mathrm{~N}(80 \mathrm{~kg})$. Obciążenie zostało dobrane doświadczalnie biorąc pod uwagę ekstremalne warunki pracy łożysk ślizgowych, a także minimalne obciążenia jakim poddawane są środki smarowe $\mathrm{W}$ testach na aparacie czterokulowym. 
The lubricity and rheological properties of magnetorheological fluids Właściwości smarne i reologiczne cieczy magnetoreologicznych

Węzeł tarcia stanowiły kulki łożyskowe, o średnicy $12,7 \mathrm{~mm}$ wykonane ze stali ŁH15 (stop żelaza Fe zawierający średnio 1\% C, 0,02\% S, 0,3\% Ni, 0,3\% Cu) w klasie dokładności 16 według normy PN-83/M-86452, zanurzone w badanej cieczy magnetoreologicznej.

Na rys. 1 przedstawiono widok aparatu czterokulowego oraz węzła tarcia tegoż urządzenia.
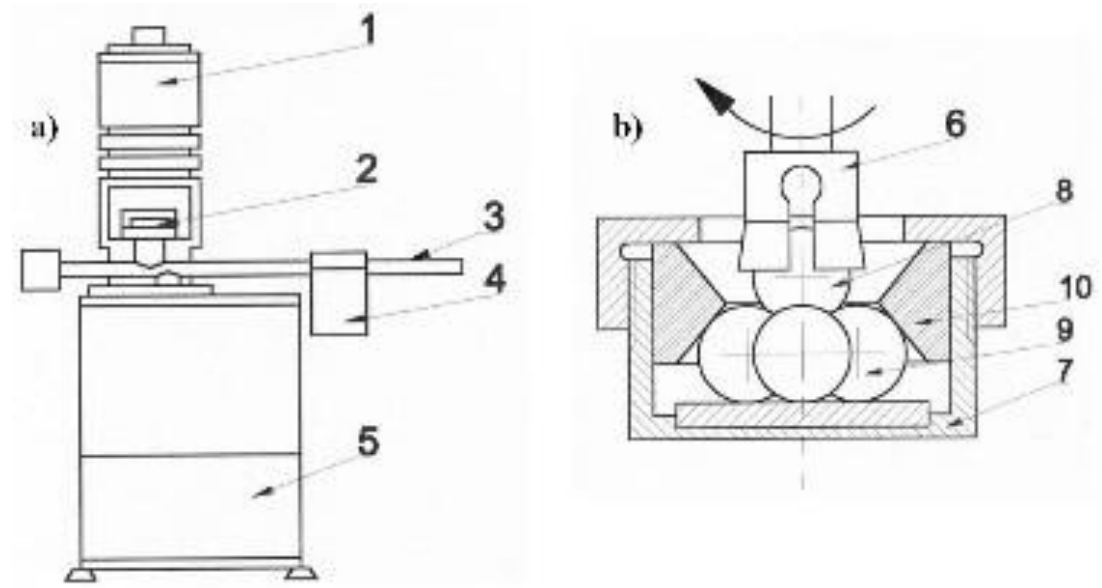

Rys. 1. Widok aparatu czterokulowego (a) oraz węzła tarcia (b);

1- silnik, 2 - węzet tarcia, 3 - ramię do obciażania, 4 - obciażenie, 5 - podstawa, 6 - uchwyt kulki realizujacej ruch obrotowy, 7 - uchwyt dla trzech kulek, 8 - nakrętka stabilizująca węzet, 9 - kulki, 10 - pierścień ustalający

Badania właściwości smarnych zostały wykonane w warunkach oddziaływana na węzeł tarcia polem magnetycznym, jak również bez wpływu tego pola. Pole magnetyczne wytwarzane było przez umieszczone na uchwycie kulek magnesy neodymowe, jak na rys.2.

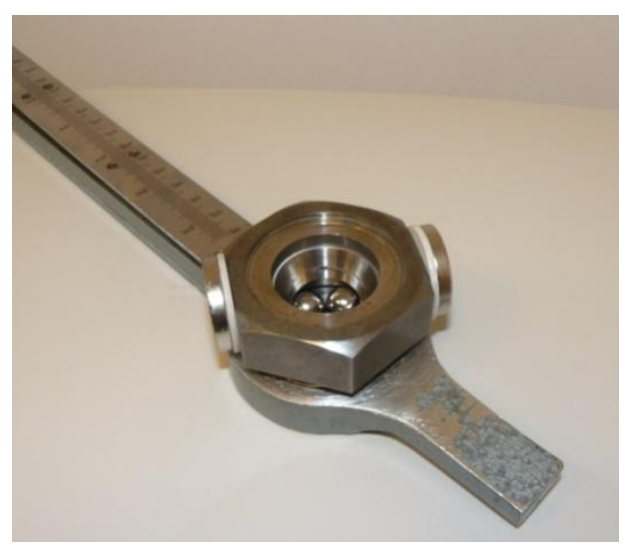

Rys. 2. Widok uchwytu elementów trących wraz z magnesami neodymowymi będacymi źródtem pola magnetycznego 
Oprócz właściwości smarnych badanych cieczy, dokonano oceny zmian ich lepkości pod wpływem przyłożonego pola magnetycznego oraz zmiany prędkości ślizgania. Oznaczenia te wykonywano na reometrze rotacyjnym ARES TA Instruments.

Pomiary prowadzono w układzie płytka - płytka (średnica płytki $\varphi=20 \mathrm{~mm}$ ) przy stałej odległość pomiędzy płytkami $1 \mathrm{~mm}$. Układ tych płytek przedstawiony został na rysunku 3.

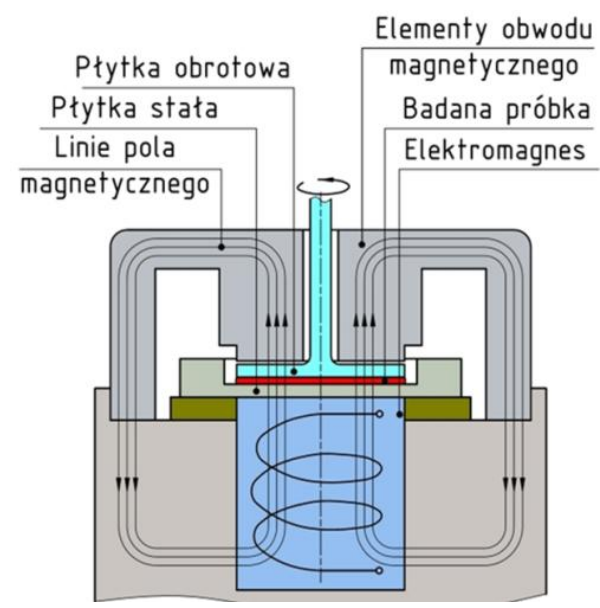

Rys. 3. Schemat oddziatywania polem elektromagnetycznym na ciecz magnetoreologiczna znajdująca się pomiędzy ptytkami roboczymi.

Badania właściwości reologicznych przeprowadzono w funkcji zmiennej szybkości ścinania w zakresie 0,1 - $630 \mathrm{~s}^{-1}$. Próbkę cieczy umieszczano na dolnej płytce podczas gdy druga płytka zanurzona $\mathrm{w}$ tej cieczy realizuje ruch obrotowy. Dla każdego z badanych materiałów wyznaczono charakterystykę reologiczną przy określonych parametrach dla trzech powtórzeń. Rejestrowano zmiany lepkości, naprężenia ścinającego oraz momentu skręcającego w funkcji szybkości ścinania. Na podstawie przeprowadzonych pomiarów zestawiono zmiany lepkości w funkcji szybkości ścinania bez pola oraz w polu magnetycznym o natężeniu $159 \mathrm{kAm}^{-1}$.

\section{Wyniki badań}

Wyniki badań smarnościowych przeprowadzonych na aparacie czterokulowym dla trzech cieczy magnetoreologicznych oraz dwóch cieczy bazowych zamieszczono w postaci wykresu na rys. 4 .

Jak wynika z otrzymanych wyników badań, największym zużyciem, a tym samym najgorszą smarnością $\mathrm{w}$ zadanych warunkach pracy cechowała się magnetoreologiczna ciecz handlowa, oznaczona jako MRF 3. Pomimo zaplanowanego testu trwającego 60 sekund, już po kilkunastu sekundach trwania testu doszło do zacierania kulek pracujących w środowisku tej cieczy, a w 25 sekundzie testu badanie zostało przerwane $\mathrm{z}$ uwagi na zespawanie kulek. 
The lubricity and rheological properties of magnetorheological fluids Właściwości smarne i reologiczne cieczy magnetoreologicznych

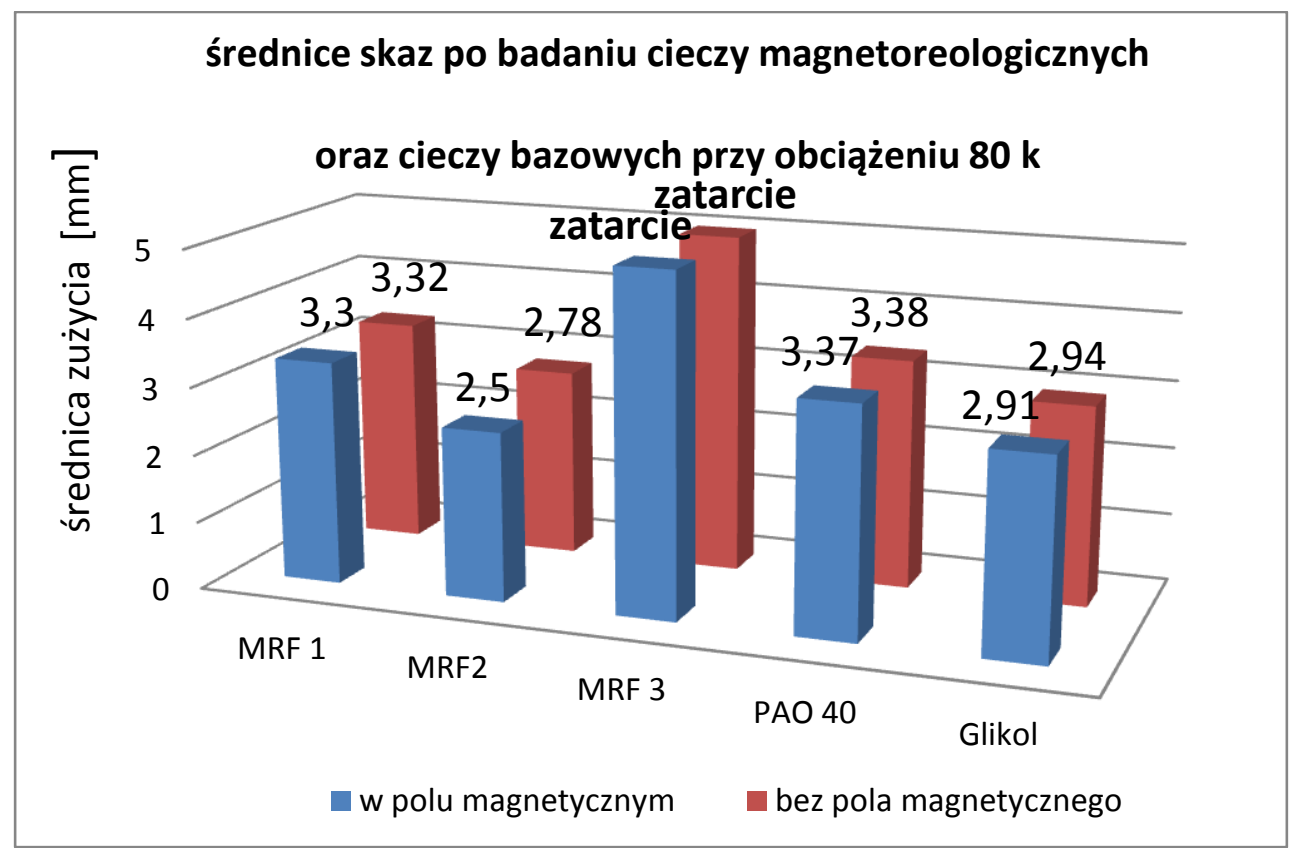

Rys. 4. Wartości zużycia węzła tarcia smarowanego cieczami magnetoreologcznymi z oddziaływaniem i bez oddzialywania polem magnetycznym.

Dużo lepszymi wynikami podczas badania smarności cechowały się ciecze MRF 1 i MRF 2. Podczas prób $\mathrm{z}$ tymi cieczami nie dochodziło do zacierania, a węzeł tarcia wytrzymał zadane obciążenie wynoszące $80 \mathrm{~kg}$. Rezultatem tarcia w środowisku cieczy magnetoreologicznych było zużycie współpracujących kulek. Najniższym zużyciem cechował się węzeł tarcia smarowany cieczą MRF 2, skomponowaną na bazie glikolu polipropylenowego. Średnia średnica śladu zużycia dla testu z cieczą na bazie glikolu polipropylenowego wyniosła $2,78 \mathrm{~mm}$ $\mathrm{w}$ warunkach bez ingerencji polem magnetycznym. Po umieszczeniu w pobliżu węzła tarcia magnesów neodymowych ślad zużycia był mniejszy i wynosił $2,50 \mathrm{~mm}$.

W przypadku testu tribologicznego z użyciem cieczy MRF 1, sporządzonej na bazie oleju PAO 40, średnice śladów zużycia były większe niż podczas badań $\mathrm{z}$ cieczą MRF 2. Wyniki eksperymentu $\mathrm{w}$ polu magnetycznym $\mathrm{i}$ bez pola magnetycznego nie różniły się od siebie znacząco i wynosiły odpowiednio $3,30 \mathrm{~mm}$ oraz $3,32 \mathrm{~mm}$.

Odnosząc uzyskane wyniki do rezultatów smarności, jakie otrzymano dla czystych baz substancji nośnych cieczy magnetoreologicznych, można zauważyć pewną analogię, polegającą na lepszych właściwościach przeciwzużyciowych zarówno glikolu jak również cieczy magnetoreologicznej sporządzonej na jego bazie, w stosunku do oleju PAO 40 i jego pochodnej. 
Biorąc pod uwagę wpływ pola magnetycznego na właściwości smarne badanych cieczy, należy stwierdzić, że jest on pozytywny w przypadku cieczy magnetoreologicznych MRF 1 i MRF 2, na co wskazują mniejsze średnice zużycia. W przypadku cieczy handlowej, wpływ pola magnetycznego nie może zostać oceniony ze względu na próby, które w obu przypadkach zakończyło się zatarciem węzła. Natomiast zgodnie z oczekiwaniami, pole magnetyczne nie miało wpływu na wyniki testu smarnościowego dla czystych cieczy bazowych (olej PAO 40 i glikol polipropylenowy).

We właściwej interpretacji otrzymanych wyników pomocny może być także pomiar gęstości badanych cieczy magnetoreologicznych. Znając gęstość cieczy bazowych, a także zawartość proszku żelaza karbonylkowego bądź gęstość cieczy magnetoreologicznych, ocenić można wpływ zawartości metalicznej fazy stałej roztworu na właściwości smarne cieczy magnetoreologicznych. Biorąc pod uwagę dane z tabeli 1, spośród cieczy magnetoreologicznych najniższą gęstość posiadała ciecz MRF 1 - 1,47 g/ $\mathrm{cm}^{3}$. Nieco wyższą gęstością cechowała się ciecz MRF 2 $1,61 \mathrm{~g} / \mathrm{cm}^{3}$, a najwyższą ciecz handlowa, której gęstość wynosiła $3,10 \mathrm{~g} / \mathrm{cm}^{3}$. Na tej podstawie można stwierdzić, że magnetoreologiczna ciecz handlowa zawierała prawie dwukrotnie więcej żelaza karbonylkowego niż ciecze MRF 1 i MRF 2. Dlatego też, prawdopodobną przyczyną gorszej smarności cieczy MRF 3 w węźle tarcia była zwiększona koncentracja twardych cząsteczek metalicznych, które doprowadziły do szybkiego zacierania. Nie mniej jednak, dodatek cząstek metalicznych do cieczy bazowych PAO 0 i glikolu polipropylenowego (ciecze MRF 1 i MRF 2), nie tylko nie spowodował zwiększenia śladu zużycia węzła tarcia, lecz zmniejszył skazę w przypadku cieczy opartej na glikolu. Mechanizm takiego zachowania nie jest znany, ale należy przypuszczać, że przyczynił się do tego nanowymiarowy dyspergator jakim jest krzemionka koloidalna, a także większe przewodnictwo cieplne glikolu w porównaniu do oleju syntetycznego.

Mając na uwadze nie tylko właściwości smarne, ale także główną właściwość cieczy magnetoreologicznych, jaką jest zmiana reologii pod wpływem zastosowania pola magnetycznego dokonano także porównania właściwości magnetoreologicznych cieczy na dedykowanym aparacie ARES.

Poniżej, na rys. 5 przedstawiono wyniki zmian lepkości 3 cieczy magnetoreologicznych w funkcji prędkości ścinania przy stałej, wynoszącej $20^{\circ} \mathrm{C}$ temperaturze, w której dokonywano oceny. Na wykresie zamieszczone są krzywe, z których te wykreślone kolorem czerwonym charakteryzują zmiany lepkości badanej cieczy pod wpływem przyłożonego pola magnetycznego o natężeniu 200 $\mathrm{mT}$, a wykreślone kolorem niebieskim - zmiany lepkości przy zerowym natężeniu pola magnetycznego. 
The lubricity and rheological properties of magnetorheological fluids Właściwości smarne i reologiczne cieczy magnetoreologicznych

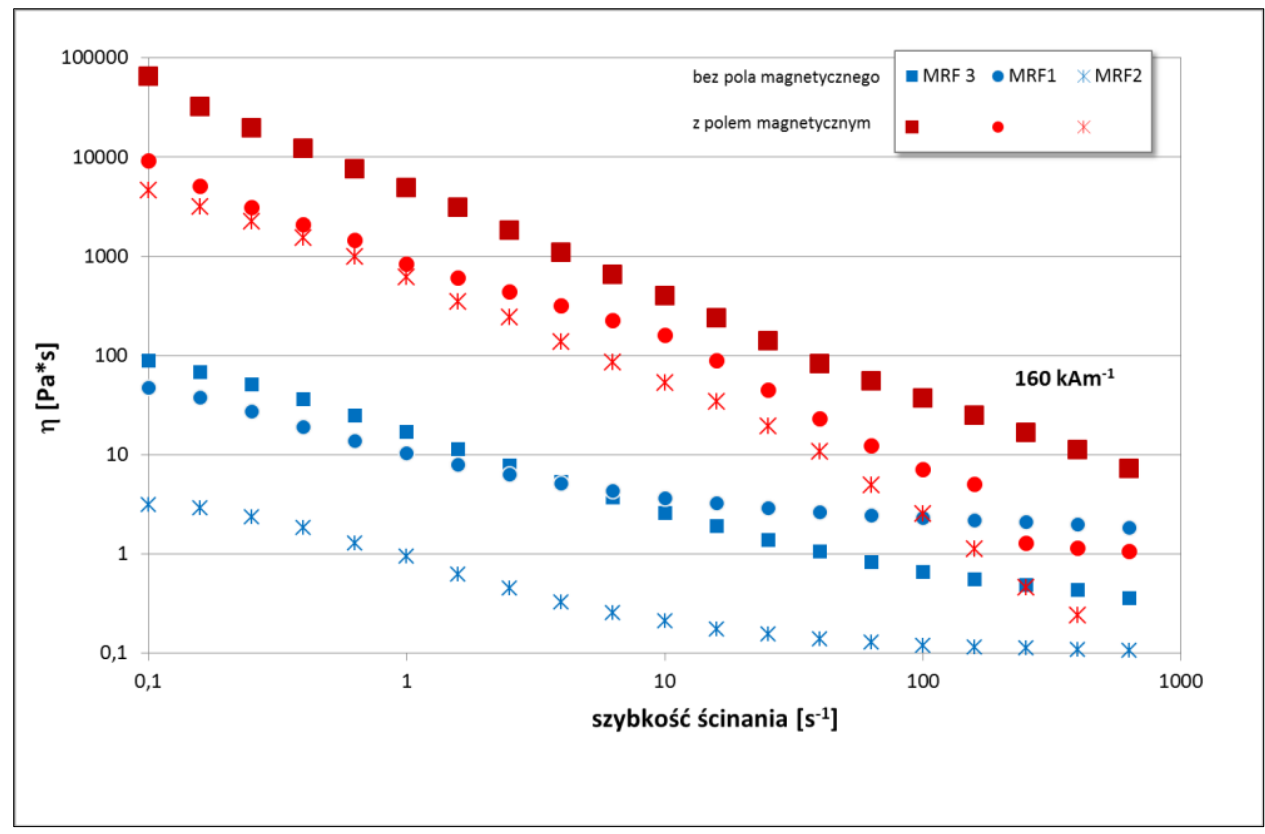

Rys.5. Zmiany reologii cieczy magnetoreologicznych przy różnych prędkościach ścinania i różnym natężeniu pola magnetycznego.

$\mathrm{Na}$ podstawie uzyskanych wyników zmian reologii trzech cieczy magnetoreologicznych: MRF 1, MRF 2 i MRF 3, należy stwierdzić, że wszystkie badane ciecze wykazywały efekt rozrzedzania ścinaniem. W całym zakresie zmian prędkości ścinania zauważalne są istotne różnice $\mathrm{w}$ reologii badanych cieczy wynikające $\mathrm{z}$ różnic natężenia pola magnetycznego, w którym ciecz ta była utrzymywania. W odniesieniu do cieczy oznaczonych jako MRF 1 i MRF2, ciecz handlowa MRF 3 charakteryzowała się wyższymi lepkościami w całym zakresie zmian prędkości ścinania. Jednocześnie ciecz ta wykazywała największą zmianę lepkości w zewnętrznym polu magnetycznym $160 \mathrm{kAm}^{-1}$ (200 mT).

Najniższe zmiany lepkości i szybkości ścinania pod pływem pola magnetycznego spośród badanych materiałów posiada ciecz MRF 1, sporządzona na bazie oleju PAO 40. Przy niskich prędkościach ścinania zmiany lepkości zachodzące pod wpływem przykładanego pola są podobne dla obu cieczy MRF 1 i MRF 2. Natomiast wraz ze wzrostem tej prędkości widoczne są zmiany lepkości zachodzące dla cieczy MRF 2, której bazą jest glikol polipropylenowy. W przypadku cieczy MRF 1, przy szybkości ścinania ok. 100 obr/s i większej, zastosowane natężenie pola magnetycznego nie ma większego wpływu na reologię tej cieczy. Pod tym względem zdecydowanie lepiej wypada ciecz MRF2. 


\section{Wnioski}

Na podstawie otrzymanych wyników własności smarnych badanych cieczy oraz zmian reologii pod wpływem oddziaływania pola magnetycznego, można przedstawić następujące wnioski:

- Badana magnetoreologiczna ciecz handlowa cechuje się bardzo słabymi właściwościami smarnymi i przeciwzatarciowymi.

- Zwiększanie zawartości cząstek metalicznych w cieczach magnetoreologicznych pogarsza własności smarne, ale poprawia właściwości magnetyczne.

- Na właściwości smarne i zachowanie cieczy magnetoreologicznych w polu magnetycznym, ma wpływ rodzaj substancji, w której zawiesza się cząsteczki metaliczne.

- Zastosowanie pola magnetycznego w węzłach tarcia smarowanych cieczami magnetoreologicznymi może mieć wpływ na poprawę właściwości smarnych tych cieczy.

- Istnieje potrzeba optymalizacji właściwości smarnych i magnetycznych cieczy magnetoreologicznych.

\section{Literatura}

[1] Kyung-In Jang, JongwonSeok, Byung-KwonMin, SangJoLee: An electrochemomechanical polishing process using magnetorheological fluid. International Journal of Machine Tools \& Manufacture 50 (2010) 869-881;

[2] Muc A., Barski M.: Ciecze magnetoreologiczne i ich zastosowania praktyczne. Wydawnictwo Politechniki Krakowskiej, Kraków 2007;

[3] Bik T.: Techniczne zastosowania ferrocieczy. Mechanik 12/2015;

[4] ASTM D 2783 - 03. Standard Test Method for Measurement of ExtremePressure Properties of Lubricating Fluids (Four-Ball Method);

[5] J. Kozłowska, K. Kulikowski, M. Leonowicz: The tribological performance of magnetorheological fluids. International Conference BALTTRIB '2013;

[6] W. H. Li and X. Z. Zhang, The effect of friction on magnetorheological fluids. , Korea Aust. Rheol. J. 20, 4550, March 24, 2008;

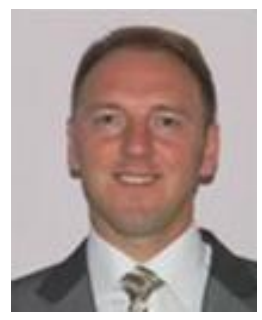

Dr inż Emil Nowiński - starszy specjalista badawczo - techniczny w Instytucie Technicznym Wojsk Lotniczych. 
The lubricity and rheological properties of magnetorheological fluids Wtaściwości smarne i reologiczne cieczy magnetoreologicznych 